\title{
ОБГРУНТУВАННЯ ВИМОГ ДО КРИТЕРІЮ ОЦІНКИ ЕФЕКТИВНОСТІ ЦИКЛОВИХ СИСТЕМ ГІДРОПРИВОДУ
}

\author{
Левченко О.В. ${ }^{1}$ \\ ${ }^{1}$ Національний технічний університет України «Київський політехнічний інститут», Київ \\ Copyright (C) 2014 by author and the journal "Automation technological and business - processes". \\ This work is licensed under the Creative Commons Attribution International License (CC BY). \\ http://creativecommons.org/licenses/by/4.0/
}
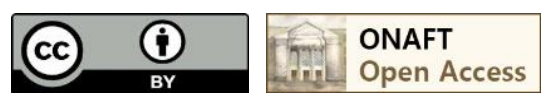

DOI: $10.15673 / 2312-3125$

Анотація

Розглянуто основні методи визначення та критерї̈ ефективності гідравлічних систем, та визначено їх переваги і недоліки. Запропоновано узагальнену модель енергоспоживання циклових систем, яка враховує функціональні характеристики виконавчих пристроїв, логіку роботи системи та рівень енергетичного споживання гідравлічної насосної станції.

Abstract

The basic methods for determining and criteria of efficiency of hydraulic systems were considered and identified their advantages and drawbacks. It was proposed generalized model of energy consumption of cyclic systems, taking into account functional characteristics of actuators, the logic of the system and the level of energy consumption of hydraulic pumping station.

Ключові слова

Енергетична ефективність, енергетичні втрати, робочий цикл, система гідроприводів.

Проблема та іiі зв'язок з науковими та практичними задачами. В загальному випадку ефективність представляє собою відношення корисного ефекту (результату) до витрат на його одержання. Ефективність циклової системи гідроприводу, так само як і ефективність будь-якої іншої системи чи окремого апарату може визначатись в залежності від обраних критеріїв оцінювання ефективності. Для технічних систем, до яких відносяться і гідравлічні системи, прийнято розглядати питання ефективності 3 точки зору рівня енергетичного споживання, тобто зводиться до визначення енергетичної ефективності. Проте енергетична ефективність системи на даному етапі розвитку техніки не $\epsilon$ визначальною 3 точки зору економіки роботи підприємств, які використовують гідравлічні системи в виробничому процесі. Тобто при визначенні енергетичної ефективності не враховується велика кількість таких факторів і показників системи, як наприклад, економічні, технологічні, технічні тощо, які в значній мірі впливають на ефективність гідравлічної системи в цілому. Більшість систем промислового гідроприводу являються цикловими, так як рух виконавчих пристроїв (гідроциліндрів) відбувається 3 однієї точки в іншу і траєкторія яких визначена механічно, тобто рух гідроциліндра відбувається прямолінійно від одного крайнього положення до іншого.

Таким чином, пропонується і $є$ актуальним визначення ефективності гідравлічної системи, яка б враховувала не тільки рівень енергоспоживання, а й економічну ефективність, тобто не лише витрату енергоносіїв, а й вартість обладнання, вартість експлуатації, обслуговування, ремонтів та інших експлуатаційних факторів роботи гідравлічної системи. Це необхідно через те, що врахування лише рівня енергоспоживання системи без врахування вартості обладнання і витрат на експлуатацію може призвести до створення системи, сумарна вартість обладнання та експлуатації якої не окуплять себе навіть за максимально можливий термін експлуатації. Тобто для порівняння 


\section{$\underline{4}$ ТЕХНІЧНІ ЗАСОБИ ТА ІНФОРМАЦІЙНІ ТЕХНОЛОГІЇ В СИСТЕМАХ УПРАВЛІННЯ}

між собою варіантів різних реалізації циклових систем гідроприводу повинен бути запропонований критерій ефективності, за допомогою якого було би можливо прогнозувати ефективність систем на конкретний проміжок часу.

Таким критерієм ефективності може бути деякий кількісний показник, що застосовується для оцінки $\mathrm{i}$ порівняння варіантів схемної реалізації гідравлічної системи. В загальному випадку показник ефективності вказує на здатність системою чи машиною виконувати технологічні чи експлуатаційні задачі при необхідності економії енергетичних, матеріальних, сировинних, трудових, екологічних ресурсів в порівнянні 3 вже існуючими гідравлічними системами. При проектуванні системи показники можуть бути розраховані 3 використанням математичних моделей, попередньо розроблених для кожного варіанту системи, яка розглядається, а при експлуатації гідравлічної системи ці показники можуть бути визначені шляхом безпосереднього виконання замірів експлуатаційних характеристик в процесі виробничого експерименту.

Викладення матеріалу та результати.

Показники, які визначають економічні властивості характеризують витрати споживача на придбання машини (ціна, транспортування, монтаж, наладка і т.д.) і затрати на експлуатацію, які включають в себе витрати на оплату праці обслуговуючого персоналу, на паливо і змащувальні матеріали, енергію, основні і допоміжні матеріали і т.д. Ефективність системи залежить від багатьох факторів, у тому числі й від ефективності складових системи. Якщо для системи в цілому визначаються як показники надійності, так і критерій ефективності, то для їі складових оцінка ефективності є недоцільною. Не варто, наприклад, розглядати ефективність застосування гідроциліндра або розподільника, як складових гідравлічної системи. Для великої сукупності об'єктів (автоматизована система керування технологічним процесом, автоматична лінія тощо) визначення ефективності є доцільним, оскільки при відмовах окремих їі частин властивості такого комплексу тільки погіршуються.

Ефективність системи може визначатись в залежності від того який параметр роботи системи або критерій $\epsilon$ основним $[1-4,6]$.

Для циклових систем гідроприводу в якості параметрів, що визначають ефективність системи використовують тиск, витрату, середню потужність, масу гідравлічного обладнання, масу робочої рідини, габаритні розміри, рівень шуму, рівень енергоспоживання та ін. Визначення ефективності системи за методикою запропонованою В.Я. Скрицьким [5] основане на характеристиках окремих гідроапаратів системи. Так наприклад, в основі оцінки ефективності (технічного рівня) об’ємних гідромашин лежать наступні показники [2, 7]:

1. Питомий показник моменту (маса, яка приходиться на одиницю крутного моменту, який створюється гідромотором)

$$
k_{M}=\frac{m_{\Gamma M}}{M_{\kappa p}}, \frac{\kappa 2}{H \cdot M},
$$

де $m_{\Gamma м}-$ маса гідромотора, кг,

$M_{\kappa p}$ - теоретичний крутний момент гідромотора, Н·м.

2. Питомий показник зусилля (маса, яка приходиться на одиницю сили, який створюється гідроциліндром)

$$
k_{M}=\frac{m_{Г Ц}}{F_{Г Ц}}, \frac{\kappa 2}{H},
$$

де $m_{\Gamma ц}-$ маса гідроциліндра, кг,

$F_{\text {Гц }}$ - теоретичне зусилля гідроциліндра, Н.

3. Питомий показник потужності (маса, яка приходиться на одиницю потужності, що створюється гідро двигуном - гідромотором або гідроциліндром)

$$
k_{P}=\frac{m}{P_{M}}, \frac{\kappa 2}{B m},
$$

де: $m$ - маса гідродвигуна, кг,

$P_{M}$ - теоретична потужність гідродвигуна, Вт.

4. Коефіцієнт компактності (маса, яка приходиться на одиницю об'єму, який займає гідравлічна машина)

$$
k_{V}=\frac{m}{V}, \frac{\kappa 2}{M^{3}},
$$

де $V-$ об'єм, описаний габаритами гідромашини, м². 


\section{4 ТЕХНІЧНІ ЗАСОБИ ТА ІНФОРМАЦІЙНІ ТЕХНОЛОГІЇ В СИСТЕМАХ УПРАВЛІННЯ}

5. Коефіцієнт енергоємності (потужність, яка створюється одиницею об'єму, який займає гідравлічна машина)

$$
k_{P / V}=\frac{P_{M}}{V}, \frac{B m}{M^{3}} .
$$

6. Коефіцієнт швидкохідності (швидкісний показник)

$$
C_{n}=n \cdot \sqrt[3]{V_{P}}, \frac{M}{c}
$$

де $n$ - частота обертання гідронасоса або гідромотора, об/с,

$V_{P}$ - робочий об'єм насоса або гідромотора, ${ }^{3}$.

7. Коефіцієнт потужності

$$
C_{P}=\Delta p \cdot n \cdot \sqrt[3]{V_{P}}, \frac{\Pi a \cdot M}{c}
$$

При розробці схемного рішення використовують комплексні критерії ефективності, які дають оцінку конструктивних і експлуатаційних показників стосовно конкретних гідрофікованих машин. Одним 3 таких показників $є$ безрозмірний критерій ефективності для гідромоторів, запропонований в [2]:

$$
K=\frac{M_{K P} \cdot n_{M} \cdot T}{g \cdot m \cdot L},
$$

де $T$ - довговічність мотора, с,

$m$ - маса гідромотора, кг,

$n_{M}$ - частота обертання валу гідромотора, об/с,

$g$ - прискорення вільного падіння, м/ $\mathrm{c}^{2}$,

$L$ - характеристичний розмір гідромотора, м $\left(L=\sqrt{\left(D_{M} \cdot L_{M}\right)}, \mathrm{M}, D_{M}\right.$ і $L_{M}$ - діаметр та довжина гідромотора, відповідно, м, причому кожний із цих параметрів може прийматися окремо, в залежності від габариту гідромотора, що лімітує машину).

Відповідно, чим вище значення критерію К, тим вища ефективність гідромотора.

На жаль критерії, які оцінюють окремі гідравлічні апарати не можуть бути використані в повній мірі при розгляді ефективності всієї гідросистеми так як на неї в більшій мірі вливає схемне рішення, тобто варіанти поєднання окремих гідравлічних апаратів в систему. Водночас аналогічний підхід може бути застосований і для гідросистеми в цілому, але з урахуванням циклограми ії роботи і визначенням критеріїв ефективності за певний період експлуатації на основі сумарних економічних витрат на впровадження конкретної схеми, іiі експлуатацію, обслуговування, ремонти та ін.

Проаналізувавши типові схемні рішення циклових систем гідроприводу встановленої потужності, що перевищує 50 кВт, а саме кувального маніпулятора МК30 Новокраматорського машинобудівного заводу «НКМЗ» (потужність 483 кВт), ливарної машини ДП-10 доменної печі Дніпродзержинського металургійного комбінату ім. Дзержинського «ДМКД» (потужність 874 кВт), автоматизованого пресу для калібрування труб D125/150 фірми Demag Нікопольського південнотрубного заводу «НПТЗ» (потужність 2560 кВт), автоматизованого пресу для пресування целюлози ВР-10000 фірми Bosch Rexroth (потужність 213 кВт), було виявлено, що для оцінки ефективності їх роботи найбільш об'єктивним був би такий показник, як єдиний комплексний критерій ефективності роботи системи за період, рівний строку ії експлуатації.

В загальному випадку ефективність роботи системи можна представити у вигляді відношення корисної роботи, виконаної цією системою, до витрат, яких система потребує впродовж життєвого циклу:

$$
E=\frac{C_{\mathrm{S}}}{D_{\mathrm{s}}},
$$

де: $C_{\mathrm{S}}=C\left(x_{j}, y_{j}, z_{j}, t\right)$ - функція повної величини цільової віддачі пристроїв гідравлічної системи,

$D_{\mathrm{S}}$ - повні затрати на проектування, виготовлення і експлуатацію гідросистеми,

$x_{j}$ - організаційні фактори (інтенсивність створення, виробництва і експлуатації),

$y_{j}$ - технічні характеристики гідравлічних пристроїв системи,

$z_{j}$ - техніко-економічні фактори (технологічність, ремонтопридатність). 


\section{4 ТЕХНІЧНІ ЗАСОБИ ТА ІНФОРМАЦІЙНІ ТЕХНОЛОГІЇ В СИСТЕМАХ УПРАВЛІННЯ}

Такий показник показує відношення виконаної корисної роботи до затрат на іiі реалізацію. Недоліком цього показника є те, що в ньому не враховується зміна енергоспоживання за визначений проміжок часу, тобто не враховуються режими роботи обладнання, його характеристики, схеми підключення та існує необхідність врахування великої кількості умов роботи системи.

На практиці неможливо врахувати всі умови ефективності при розгляді кожного типового схемного рішення. Це пов'язано з їх великою кількістю та невизначеністю, і відповідно, складністю розрахунку для типових схем. Тому доцільним $\epsilon$ розрахунок критерію ефективності 3 урахуванням експлуатаційного (умови та режим експлуатації, технологічний цикл, енергоспоживання) та економічного показників, тобто можна записати у вигляді:

$$
E=\frac{S_{\Sigma}+T_{\Sigma}}{T_{C}}
$$

де $E$ - ефективність роботи системи,

$S_{\Sigma}$ - приведений показник, який враховує сумарні економічні витрати на етапі створення системи,

$T_{\Sigma}$ - показник, який враховує технологічні витрати за весь період експлуатації системи,

$T_{C}$ - строк експлуатації установки.

Економічні витрати повинні враховувати витрати на передпроектну підготовку, проектування, витрати на створення системи (витрати на закупівлю обладнання, яке входить до складу системи).

$$
S_{\Sigma}=D_{P}+M_{C}+A_{\partial}
$$

де: $D_{P}-$ витрати на передпроектну підготовку та проектування,

$M_{C}$ - витрати на створення (модернізацію) гідросистеми,

$A_{\partial}$ - додаткові витрати.

Відповідно експлуатаційна складова показника ефективності повинна враховувати витрати, які здійснюються в процесі експлуатації системи (енергетичні витрати, відповідно до технологічного циклу, ремонти) та залежить від довговічності роботи системи, ресурсу окремих пристроїв, режимів роботи обладнання та експлуатаційного циклу:

$$
T_{\Sigma}=f\left(R_{T}, T_{C}, M_{T}, C_{O P}\right)
$$

де: $R_{T}$ - витрати на експлуатацію за період експлуатації гідравлічної системи,

$M_{T}$ - режим роботи обладнання відповідно до технологічного циклу,

$C_{O P}$ - експлуатаційний цикл роботи обладнання, тобто тривалість однієї зміни роботи обладнання 3 урахуванням експлуатаційних витрат часу, год.

За результатами проведеного аналізу та досліджень встановлено, що визначення енергетичних характеристик багатопривідних циклових систем гідроприводів має ціллю прогнозування рівня енергоспоживання систем гідроприводів на етапі до початку проектування системи. Для прогнозування характеристик гідросистеми потрібна модель в загальному вигляді для основних типів схемних рішень. Задачами використання моделі $є$ визначення енергетичних характеристик за умов збереження функціональних характеристик роботи циклової гідросистеми. Розробка моделі має два напрямки, такі як отримання характеристик, що стосуються роботи системи i характеристик окремих пристроїв, які входять до іiі складу. Для отримання рівня енергоспоживання модель системи попередньо повинна мати можливість визначення енергетичних характеристик (діаграми сумарної витрати, діаграми тиску, затраченої потужності, споживаної енергії).

Враховуючи велику кількість параметрів кожного виконавчого пристрою та кількість приводів у складі системи, моделювання роботи системи зводиться до використання середньотактових показників роботи системи. Рівень енергоспоживання приводами за один такт визначається по кількості приводів, які спрацьовують в такті, їх середній потужності впродовж такту та тривалості такту. Загальний рівень енергоспоживання за робочий цикл визначається сумою енерговитрат в кожному з тактів робочого циклу. Рівень затраченої енергії визначається корисною енергією та втратами в системі, які в свою чергу залежать від схемного рішення та енергетичної неузгодженості між апаратами різних рівнів.

Таким чином, модель системи може бути представлена у вигляді трьох складових: функціональної, логічної та енергетичної. В функціональній складовій декларативно можуть бути задані параметри, які визначають корисну роботу системи (тиск та витрата) та формують корисну потужність, з урахуванням конструктивних характеристик 


\section{4 ТЕХНІЧНІ ЗАСОБИ ТА ІНФОРМАЦІЙНІ ТЕХНОЛОГІЇ В СИСТЕМАХ УПРАВЛІННЯ}

(наприклад, ефективна площа поршневої та штокової порожнини), експлуатаційних функцій (навантаження та швидкість) та коефіцієнтів втрат (наприклад, ККД апаратів) для кожного виконавчого пристрою.

Функціональна складова представляє собою систему виразів, які описують енергоформуючі характеристики усіх приводів системи:

$$
\left\{\begin{array}{l}
P_{1}, Q_{1}, N_{1} \ldots \\
P_{2}, Q_{2}, N_{2} \ldots \\
P_{n}, Q_{n}, N_{n} \ldots
\end{array}\right\},
$$

де $P_{n}$ - тиск, необхідний для спрацювання n-го приводу, Па,

$Q_{n}$ - витрата, необхідна для спрацювання n-го приводу, ${ }^{3} / \mathrm{c}$,

$N_{n}$ - потужність п-го приводу, Вт.

Відповідно енергоформуючі характеристики кожного приводу системи функціонально визначаються через конструктивні характеристики та експлуатаційні навантаження та швидкості:

$$
P_{i}=f(s, q, M, F, m), Q_{i}=f(s, q, v, \omega), N_{i}=f\left(P_{i}, Q_{i}\right)
$$

де $s$ - ефективна площа робочої порожнини, м²,

$q$ - робочий об'єм гідромотора, м $^{3} /$ б,

$M$ - крутний момент, Н·м,

$m$ - маса рухомих частин, кг,

$v$ - швидкість робочого органу, м/с,

$\omega$ - кутова частота, рад/с.

Функціональна складова є спільною для різних класів схемних рішень, які використовуються для реалізації системи. Це пояснюється тим, що не залежно від схемної реалізації, функції, які виконують виконавчі пристрої, повинні відповідати технічному завданню на проектування системи.

В логічній складовій, яка описує циклограму системи, визначаємо кількість тактів робочого циклу, кількість приводів які спрацьовують в кожному такті та тривалість такту. Робочий цикл системи може бути представлений послідовністю прямих та зворотних операцій і має вигляд:

$$
1-2-\overline{1}, 3-4-\overline{3}, 5, \overline{2}-\overline{5}-\overline{4}
$$

де $i, \bar{i}$ - пряма та зворотна дія і-го приводу.

Логіка спрацювання приводів реалізує циклограму роботи системи, тобто зміну стану системи в часі. Логічна складова, як і функціональна, є спільною для типових схемних рішень, так як реалізує послідовність виконання прямих та зворотних операцій виконавчих пристроїв у відповідності до експлуатаційного циклу, який $є$ незмінним для усіх варіантів схемної реалізації системи.

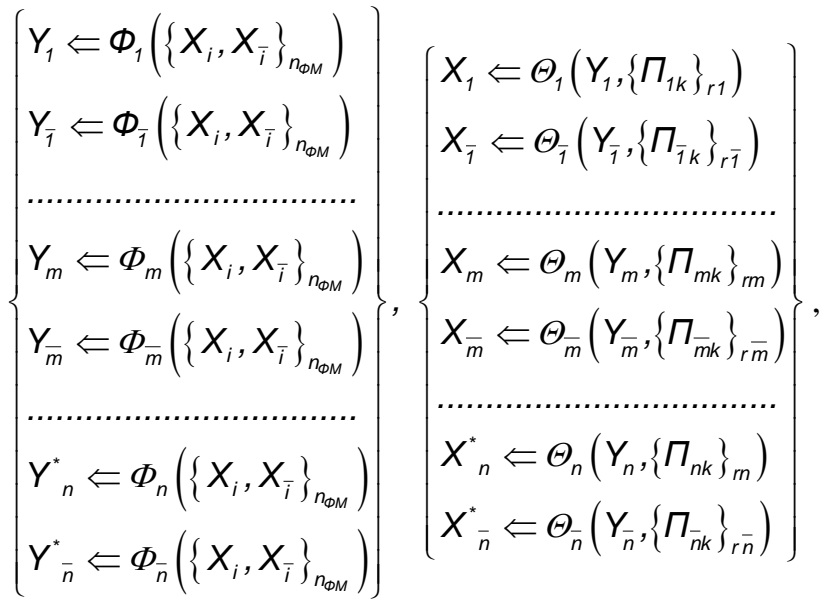

де $Y_{i}, Y_{\bar{i}}\left(Y_{i}^{*}, Y_{\bar{i}}^{*}\right)$ - керуюча команда на включення прямої та зворотної операції і-го приводу (* для апаратів енергетичного рівня), 


\section{$\underline{4}$ ТЕХНІЧНІ ЗАСОБИ ТА ІНФОРМАЦІЙНІ ТЕХНОЛОГІЇ В СИСТЕМАХ УПРАВЛІННЯ}

$X_{i}, X_{\bar{i}}\left(X_{i}^{*}, X_{\bar{I}}^{*}\right)$ - сигнали стану і-го приводу (* для апаратів енергетичного рівня),

$\Pi_{i k}, \Pi_{\overline{i k}}-$ пряма та зворотна функція і-го приводу в к-му такті,

$\Phi_{i}, \Phi_{\bar{i}}, \Theta_{i}, \Theta_{\bar{i}}$ - функції формування прямих та зворотних керуючих команд і сигналів стану і-го приводу.

Енергетична складова визначає рівень енергоспоживання в такті та енергоспоживання системи за робочий цикл. Дія кожного такту керується умовами на включення $\left\{Y_{i}, Y_{\bar{i}}\right\}_{n}$ кожного привода системи 3 логічної складової. За функціями визначаємо середньотактову потужність приводів та тривалість такту. По кількості і тривалості тактів робочого циклу та середньотактовій потужності визначаємо рівень енергоспоживання за робочий цикл та середньоциклові показники потужності.

Величину корисної енергії визначаємо для класу схемних рішень, що розглядаються, по спільній функціональній (навантаження, швидкість) та логічній складовій (умова включення приводу, тривалість такту):

$$
E_{K}=\sum_{j=1}^{k} N_{j} \cdot t=\sum_{j=1}^{k}\left(\sum_{i=1}^{n}\left(y_{i} \cdot F_{i} \cdot v_{i}+y_{i} \cdot M_{i} \cdot \omega_{i}\right)\right) \cdot t,
$$

де $N_{j}$ - сумарна середньотактова корисна потужність приводів, які спрацьовують в ј-му такті, Вт,

$k$ - кількість тактів робочого циклу,

$y_{i}$ - умова включення і-го приводу,

$n$ - кількість приводів системи.

Даний підхід дозволяе отримати рівень корисної енергії, спожитої системою за одиничний цикл. Для розрахунку рівня затраченої енергії системи, для кожного класу проводимо врахування втрат за рахунок схемної неузгодженості енергетичного та виконавчого рівня та факторів, які є типовими для багатопривідних циклових систем об'ємних гідроприводів: одночасна робота декількох виконавчих пристроїв, температура робочої рідини, нерівномірність навантаження на виконавчих пристроях. Тобто, при визначенні рівня енергоспоживання враховуємо втрати енергії для кожного схемного рішення по траєкторії енергетичного потоку та враховуємо зворотній вплив величини дисипації енергії на рівень енергоспоживання системи.

Рівень затраченої енергії системи визначається корисною енергією та величиною енергетичних втрат:

$$
E_{3}(t)=E_{K}(t)+E_{B}(t),
$$

де $E_{B}(t)$ - втрати енергії в системі, Вт·с.

Рівень енергоспоживання типових схемних рішень відрізняється за рахунок різних енергетичних втрат, які визначаються різницею корисної та затраченої потужності та тривалості такту.

Енергетичні втрати системи з постійним тиском та витратою $(p$-const, $Q$-const $)$ визначаються:

$$
E_{B}=\sum_{j=1}^{k}\left(\underset{i=1}{n} X\left(P_{i}\right) \cdot M_{i=1}^{n} X\left(Q_{i}\right)-P_{i} \cdot Q_{i}\right) \cdot t+E_{K} \cdot K,
$$

де $K$ - коефіцієнт, який враховує зміну енергоспоживання за рахунок втрат в гідроапаратах, нагріву робочої рідини, частоти реверсування, зміни експлуатаційних навантажень на виконавчому пристрої.

На першому етапі розрахунку енергетичних втрат системи 3 постійним тиском i витратою визначаємо за допомогою функціональної складової максимальний тиск та витрату шляхом потактового порівняння необхідних для роботи виконавчих пристроїв тиску та витрати. При чому, якщо в такті спрацьовує декілька виконавчих пристроїв, максимальним тиском є найбільший необхідний тиск, а максимальна витрата визначається сумою необхідних витрат всіх виконавчих пристроїв, які спрацьовують в такті.

Енергетичні втрати системи з постійним тиском та змінною витратою ( $p$-const, $Q$-var) :

$$
E_{B}=\sum_{j=1}^{k}\left(\underset{i=1}{M A} X\left(P_{i}\right)-P_{i}\right) \cdot Q_{i} \cdot t+E_{K} \cdot K .
$$

Енергетичні втрати в системі визначаються добутком витрати, необхідної для роботи приводів в такті, та різницею максимального за робочий цикл і номінального тиску в кожному такті і тривалістю такту.

Енергетичні втрати системи зі змінним тиском та постійною витратою $(p-\mathrm{var}, Q$-const $)$ :

$$
E_{B}=\sum_{j=1}^{k}\left(\underset{i=1}{n} \underset{n}{A}\left(Q_{i}\right)-Q_{i}\right) \cdot P_{i} \cdot t+E_{K} \cdot K .
$$




\section{$\underline{4}$ ТЕХНІЧНІ ЗАСОБИ ТА ІНФОРМАЦІЙНІ ТЕХНОЛОГІЇ В СИСТЕМАХ УПРАВЛІННЯ}

Для системи зі змінним тиском та постійною витратою на першому етапі визначається максимальна витрата при потактовому порівнянні. Далі визначаються втрати в системі добутком номінального тиску та різниці максимальної та номінальної витрат і тривалості такту.

Енергетичні втрати системи зі змінним тиском та змінною витратою ( $p$ - var, $Q$ - var $)$ :

$$
E_{B}=E_{K} \cdot K \text {. }
$$

\section{Висновки}

За допомогою рівня енергоспоживання та часових і експлуатаційних параметрів роботи системи 3 різними схемними реалізаціями, таких як тривалість експлуатації системи, вартість обладнання, ресурс обладнання та 3 врахуванням вимог до показників ефективності роботи гідросистеми може бути запропонований комплексний критерій ефективності для кожного класу систем. Цей критерій може бути використаний для порівняння між собою варіантів схемної реалізації гідравлічної системи та за його допомогою можуть бути надані рекомендації щодо розробки енергетично раціонального схемного рішення. Запропонована трирівнева модель циклової системи гідроприводів в перспективі може бути орієнтована на визначення інших характеристик, таких як вибір типу робочої рідини, способів фільтрації, термінів заміни робочої рідини і фільтруючих елементів, визначення температурних режимів роботи системи і відповідно вибору оптимальної схеми підігріву й охолодження робочої рідини, розробку графіків проведення планово-попереджувальних ремонтів, проведення превентивних ремонтів та оглядів, застосування систем рекуперації дисипованої енергії. В процесі досліджень встановлено, що для прогнозування енергоспоживання 3 точністю достатньою для отримання енергозаощаджуючого схемного рішення необхідне проведення моделювання роботи системи. Алгоритм моделювання має враховувати втрати енергії вздовж енергетичного потоку в структурі системи та відповідати логіці функціонування пристроїв виконавчого рівня, рівня контролю, рівня керування та узгодження параметрів енергетичного рівня. Сформовано вимоги до критерію енергетичної ефективності системи та запропоновано узагальнену модель роботи багатопривідних циклових систем, придатну для прогнозування об’ єму споживання енергії під час експлуатації.

\section{Література}

1. Панамарьова О.Б. Узагальнений критерій для оцінки показників технічного рівня гідроагрегату живлення гідросистем/О.Б. Панамарьова//Механіка та машинобудування.Х.:НТУ «ХПІ».-2011.-№2’2011. -С. 34- 42.;

2. Объемный гидропривод и гидропневмоавтоматика: учеб. пособие / Г.А. Аврунин, И.В. Грицай, И.Г. Кириченко и др. - Х.: ХНАДУ. - 2008. - 412 с.;

3. [Глузман Г.Л. Надежность установок и систем управления / Глузман Г.Л., Падерно И.П. / - М. - Л., изд-во «Машиностроение», 1966. - 212 с.;

4. Базовский И. Надежность, теория и практика. - М., изд-во «Мир», 1965, - 376 с.,

5. Скрицкий В.Я. Эксплуатация промышленных гидроприводов / Скрицкий В.Я., Рокшевский В.А. / М.: Машиностроение, 1984. - 176c.;

6. Беленков Ю.А. Нейман В.Г. Надежность объемных гидроприводов и их элементов. - М., «Машиностроение», 1977. - 168 с.];

7. Система показателей качества продукции. Гидроприводы объемные, пневмоприводы, и смазочные системы. Номенклатура показателей: ГОСТ 4.37-90. - М.: Издательство стандартов, 1990. - 39 с.

\section{References}

1. Panamar'ova O.B. Uzahal'nenyy kryteriy dlya otsinky pokaznykiv tekhnichnoho rivnya hidroahrehatu zhyvlennya hidrosystem/O.B. Panamar'ova//Mekhanika ta mashynobuduvannya.-K.: NTU«KPI».-2011.-\#2"2011.-S.34- 42.;

2. Obъemnyy hydropryvod y hydropnevmoavtomatyka: ucheb. posobye / H.A. Avrunyn, Y.V. Hrytsay, Y.H. Kyrychenko y dr. - Kh.: KhNADU. - 2008. - 412 s.;

3. [Hluzman H.L. Nadezhnost' ustanovok y system upravlenyya / Hluzman H.L., Paderno Y.P. / - M. - L., yzd-vo «Mashynostroenye», 1966. - 212 s.;

4. Bazovskyy Y. Nadezhnost', teoryya y praktyka. - M., yzd-vo «Myr», 1965, - 376 s.,

5. Skrytskyy V.Ya. Ekspluatatsyya promyshlennykh hydropryvodov / Skrytskyy V.Ya., Rokshevskyy V.A. / M.: Mashynostroenye, 1984. - 176s.;

6. Belenkov Y.A. Neyman V.H. Nadezhnost' obъemnykh hydropryvodov y ykh elementov. - M., «Mashynostroenye», 1977. - 168 s.];

7. Systema pokazateley kachestva produktsyy. Hydropryvody obъemnye, pnevmopryvody, y smazochnye systemy. Nomenklatura pokazateley: HOST 4.37-90. - M.: Yzdatel'stvo standartov, 1990. - $39 \mathrm{~s}$. 